\title{
Asihan (Mantra) sebagai adat budaya masyarakat Lampung Pepadun
}

\author{
Windo Dicky Irawan', Sumarno², Juhardi Basri3 \\ 1,2,3 Universitas Muhammadiyah Kotabumi \\ Correpondence: abubilqis9o@gmail.com
}

\begin{abstract}
This research is motivated by an interest in the asihan or mantra of the Lampung Pepadun cultural community, North Lampung Regency which functions to strengthen mental and self-confidence, expel evil spirits, treat sick people, defeat the forces of nature, and subdue one's heart. The purpose of this study is to describe the function and meaning of asihan or mantra for the culture of the people of Lampung Pepadun, North Lampung Regency. The data in this study were taken from the traditional elders of Lampung Pepadun in North Lampung district. Data were collected by observation, interview, and recording methods.
\end{abstract}

Keywords: Asihan, culture, Lampung people

\section{Pendahuluan}

Kebudayaan di Indonesia tentunya berkaitan dengan tradisi. Tradisi lisan tentu tidak akan lepas dari sastra lisan. Sastra lisan merupakan ekspresi kesusastraan masyarakat suatu kebudayaan yang disebarluaskan secara turun-menurun melalui lisan, sehingga masyarakat memiliki bahasa yang indah melalui sastra lisan.

Lampung memiliki sastra lisan yang dahulu sering digunakan oleh masyrakat atau tetua Lampung dalam kegiatan sehari-hari. Sastra lisan Lampung tentunya milik masyarakat Lampung yang bersifat anonim. Sastra itu merupakan bagian yang sangat penting bagi masyarakat Lampung yang tentunya juga bagian dari kebudayaan nasional. Menurut (James, 2007) “terdapat empat fungsi sastra lisan, yaitu 1) sebagai sistem proyeksi yakni sebagai alat pencermin angan-angan suatu kolektif, 2) sebagai alat pengesahan pranata-pranata dan lembaga-lembaga kebudayaan, 3) sebagai alat pendidikan anak dan 4) sebagai alat pemaksa dan pengawas agar norma-norma masyarakat akan selalu dipatuhi anggota kolektifnya". Menurut (Sanusi, 2013) "sastra lisan Lampung terdiri atas lima jenis, yaitu 1) peribahasa, 2) teka-teki, 3) cerita rakyat, 4) puisi, dan 5) mantra”.

Setiap tradisi pasti akan terus berkembang. Perkembangan itu selalu mengikuti perubahan sosial. Perubahan itu tidaklah melenceng jauh dari 
akarnya. Namun kenyataanya, tidak pada tradisi budaya Lampung. Tingginya globalisasi dan mobilitas sosial, serta meluasnya penyebaran komunikasi ke daerah-daerah seperti TV, radio, media berbasis web, dan surat kabar telah mempengaruhi kemajuan budaya Lampung, sehingga asihan (mantra) sudah kurang mendapat perhatian di masyarakat Lampung Pepadun, terutama generasi muda. Hal ini berdasarkan pra pengamatan peneliti yang juga sebagai suku asli Lampung, masyarakat Lampung Pepadun (khususnya pemuda-pemudi Lampung) sedikit sekali yang mengetahui bentuk-bentuk tradisi budaya Lampung, yang salah satunya adalah Mantra. Hal inilah yang mengancam punahnya mantra dalam masyarakat Lampung Pepadun.

Pada umumnya masyarakat Lampung adalah orang-orang yang tinggal menetap di Lampung. Namun pada hakikatnya, masyarakat Lampung merupakan masyarakat Lampung yang asli lahir dari keturunan nenek moyang bersuku Lampung (Irawan, 2019). Menurut (Hadikusuma, 1988) "masyarakat Lampung pepadun sendiri terbagi menjadi empat daerah, yaitu 1) Abung, 2) Tulang Bawang, 3) Way Kanan/Sungkai, dan 4) Pubiyan. Masyarakat Lampung pepadun memiliki dua dialek yang berbeda. Orang-orang Way Kanan/Sungkai menggunakan dialek A (api), dan orang-orang Abung dan Tulang Bawang menggunakan dialek $\mathbf{O}$ (nyo)".

Pada paragaf awal telah diuraikan bahwa masyarakat Lampung Pepadun terdapat sastra lisan Lampung. Salah satunya adalah asihan (mantra). Asihan (mantra) adalah "perkataan atau ucapan yang dapat mendatangkan kekuatan gaib, seperti dapat menyembuhkan, dapat mendatangkan celaka, dapat menguatkan mental, dan dapat melakukan hal-hal lain sebagainya" (Sanusi, 2013). Sementara menurut (Rani, 1996) "mantra adalah karya sastra lama yang berisikan puji-pujian terhadap sesuatu yang gaib ataupun sesuatu yang dianggap harus dikeramatkan seperti dewa-dewa, roh-roh, binatang-binatang seperti harimau ataupun Tuhan”.

Mantra dapat dipahami dan dianalisis melalui sebuah teori. Teori yang diacu adalah menggunakan teori yang dikembangkan oleh Riffaterre dengan pembacaan heuristik dan hermeneutik. Pembacaan heuristik adalah pembacaan yang langsung mengkaji dari kata per kata atau kalimat per kalimat dalam mantra, sehingga kata-kata atau kalimat-kalimat dalam mantra mempunyai arti yang secara denotatif atau makna yang sebenarnya. "Dalam pembacaan heuristik, sajak dibaca berdasarkan konvensi bahasa atau sistem bahasa sesuai dengan kedudukan bahasa sebagai sistem semiotik tingkat pertama" (Pradopo, 2002). Pembacaan hermeneutik adalah pembacaan yang bermuara pada ditemukannya satuan makna puisi utuh dan terpadu. Puisi harus dipahami sebagai sebuah satuan yang bersifat struktural atau bangunan yang tersusun dari 
berbagai unsur kebahasaan. Oleh karena itu, pembacaan hermeneutik pun dilakukan secara struktural. Artinya, pembacaan itu bergerak secara bolak-balik dari satu bagian ke keseluruhan dan kembali ke bagian yang lain dan seterusnya.

Selain itu, menurut pendapat (Pradopo, 2002) "pembaca dapat menggunakan hubungan intertekstual yaitu hipogram". Hipogram adalah teks yang menjadi latar penciptaan teks lain atau sajak yang menjadi latar penciptaan sajak yang lain. Seringkali sebuah sajak baru mendapat makna hakikinya bila disejajarkan dengan sajak yang menjadi hipogramnya. Jadi, mantra itu tidak dapat dilepaskan hubungan kesejarahannya dengan mantra sebelumnya.

Sehubungan dengan itu, untuk dapat memahami sebuah mantra harus mengerti bahasa mantra tersebut, untuk itu digunakan teori terjemahan untuk menerjemahkan bahasa mantra. Berkaitan dengan pernyataan di atas, (Hutomo, 1991) menyatakan bahwa "teks lisan yang sudah dikumpulkan oleh seorang peneliti perlu diterjemahkan ke dalam bahasa lain”. Sejalan dengan pernyataan tersebut, (Simatupang, 1999) menyimpulkan definisi terjemahan adalah "mengalihkan makna yang terdapat dalam bahasa sumber ke dalam bahasa sasaran dan mewujudkannya kembali di dalam bahasa sasaran dengan bentukbentuk yang sewajarnya mungkin menurut aturan-aturan yang berlaku dalam bahasa sasaran".

Berdasarkan latar belakang masalah di atas, rumusan masalah penelitian ini adalah "Bagaimanakah bentuk, makna dan fungsi mantra atau asihan pada masyarakat Lampung Pepadun di Lampung Utara?”

Tujuan penelitian ini adalah 1) untuk mengetahui bentuk, makna, dan fungsi mantra atau asihan pada masyarakat Lampung Pepadun di Lampung Utara, dan 2) untuk melestarikan budaya Lampung.

\section{Metode}

Metode Penelitian Penelitian ini menggunakan pendekatan kualitatif dengan metode deskriptif. "Metodologi kualitatif sebagai prosedur penelitian yang menghasilkan data deskriptif berupa kata-kata tertulis atau lisan dari orangorang dan prilaku yang dapat diamati” (Moleong, 2005). Jenis dan metode ini tepat digunakan dalam penelitian ini karena data penelitian bersumber dari data lisan yakni masyarakat Lampung Pepadun di Lampung Utara.

Data dalam penelitian ini adalah tuturan dalam bentuk kalimat yang di dalamnya terdapat mantra atau asihan yang digunakan oleh masyarakat Lampung Pepadun di Lampung Utara. Sumber data dari penelitian ini adalah tuturan masyarakat Lampung Pepadun di Lampung Utara yang berbentuk mantra atau asihan yang diambil dari lima tetua adat Lampung Pepadun di 
Sungkai Selatan. Teknik pengumpulan data yang digunakan dalam penelitian ini adalah (1) Observasi, (2) Perekaman, dan (3) Wawancara

\section{Hasil dan pembahasan}

Mantra atau asihan merupakan tradisi adat masyarakat Lampung sejak dulu. Mantra merupakan ucapan lisan yang dapat menimbulkan kekuatan gaib. Mantra dalam budaya Lampung disebut dengan asihan. Pada zaman dulu masyarakat Lampung dalam setiap kegiatan ataupun acara masyarakat tidak terlepas dari mantra. Kegiatan-kegiatan yang menggunakan mantra pada masyarakat Lampung Pepadun dahulu adalah pengobatan, mengusir roh jahat, memperkuat mental dan rasa percaya diri, mengalahkan kekuatan alam sekitar, dan menundukkan hati seseorang.

Penelitian mantra atau asihan ini untuk mengetahui bentuk, makna, dan fungsi mantra atau asihan pada masyarakat Lampung Pepadun di Lampung Utara. guna melestarikan budaya daerah (Lampung) yang hampir punah, sebagaimana masyrakat Lampung (khususnya generasi muda) yang sudah hampir tidak lagi mengetahui dan mengaplikasinnya dalam kehidupan seharihari. Hal tersebut menjadi dasar atau motivasi dalam penelitian ini.

Adapun hasil penelitian mantra atau asihan yang peneliti wawancara pada lima narasumber adalah sebagai berikut.

\section{Mantra atau asihan menundukkan hati sesorang}

\section{a. Judul: Busalin \\ Kucatik niku baju \\ Baka dandanku lapah \\ Sapa sai ngenah \\ tunduk unyin segala}

\author{
Judul: Bersalin \\ Ku ambil kau baju \\ Untuk pakaianku pergi \\ siapa yang melihat \\ tertunduk semua
}

Mantra atau asihan di atas merupakan bentuk puisi lama yang diperoleh dari narasumber bernama Ibu Tuan Merumpun berasal dari Lampung Way Kanan. Maksud mantra atau asihan di atas ialah agar penglihatan setiap orang yang melihat pengguna mantra tersebut terlihat menarik, selalu baik, cantik atau tampan dan sempurna, bahkan tidak ada satupun kekurangan di dalam diri pengguna mantra atau asihan tersebut. Mantra atau asihan di atas dibaca rutin oleh setiap pengguna dengan keyakinan penuh dan meminta pertolongan Allah setiap pagi, siang, sore atau bahkan pada saat ingin bertemu seseorang.

b. Judul: Ngerang Telesan

Titih gedung jenungmu pembuyu

Mula sai jenungmu telesan

Kantu malaikat ngulih ulih
Judul: Menjemur Basahan Pinggir gedung namamu genter

Maka namamu basahan Mungkin malaikat-bertanya tanya 
Niku telesan nabi muhammad cakmu.

Kau basahan Nabi Nuhammad kata mu.

Mantra atau asihan di atas merupakan bentuk puisi lama yang diperoleh dari narasumber atas nama Ibu Inap Triyana berasal dari Tiyuh Sinar Galih Ungak. Maksud mantra atau asihan di atas ialah agar setiap manusia menyukai pengguna mantra tersebut sebagaimana menyukai Nabi Muhammad Saw. Sudah diketahui bersama bahwa sifat yang dimilik oleh nabi Muhammad saw. terdiri atas empat sifat, yaitu siddiq (jujur), amanah (dapat dipercaya), fathanah (cerdas), dan tabligh (menyampaikan). Mantra atau asihan di atas dibaca rutin oleh setiap pengguna dengan keyakinan penuh dan meminta pertolongan Allah setiap pagi, siang, sore atau bahkan pada saat ingin bertemu seseorang.

c. Judul: Ilmu Bumiyah Muli Meranai

Kak kujak yang mejong tumpak Tumpak busila dija ji, pok ku mejong

Dipangku anak mata
Judul: Ilmu Pemikat Bujang Gadis

Ku ajak dia duduk merenung Duduk bersila, di tepmatku duduk

Di pangku anak mata

Mantra atau asihan di atas merupakan bentuk puisi lama yang diperoleh dari narasumber atas nama Darwis berasal dari Tiyuh Bumi Tinggi. Maksud mantra atau asihan di atas ialah agar menarik perhatian setiap yang orang yang memandang/menatap mata setiap orang pengguna mantra baik itu wanita maupun laki-laki, sehingga pengguna mantra tersebut menjadi fokus utama bagi yang menandang/menatap. Mantra atau asihan di atas dibaca rutin oleh setiap pengguna dengan keyakinan penuh dan meminta pertolongan Allah setiap pagi, siang, sore atau bahkan pada saat ingin bertemu seseorang.

d. Judul: Pungijak Jak Cahya

Terpisah namamu adik Terkadim namamu tubuh Cahyaku kuat cahyaku pakai Cahya buginda Rasulullah

\author{
Judul: Ilmu Pembuka Aura \\ Terpisah namamu adik \\ Terkagum namamu tubuh \\ Cahaya saya adalah cahaya pakai \\ Cahaya baginda Rasullah
}

Mantra atau asihan di atas merupakan bentuk puisi lama yang diperoleh dari narasumber atas nama Ibu Sunan berasal dari Tiyuh Negara Ratu. Maksud mantra atau asihan di atas ialah agar setiap tubuh pengguna mantra memiliki aura yang terbuka sebagaimana auranya Rasulullah saw. yang penuh wibawa, dan disegani serta dikagumi oleh setiap manusia, sehingga orang pun akan juga memiliki sikap hormat, segan, dan kagum terhadap pengguna mantra. Mantra atau asihan di atas dibaca rutin oleh setiap pengguna dengan keyakinan penuh dan meminta pertolongan Allah setiap pagi, siang, sore atau bahkan pada saat ingin bertemu seseorang. 
e. Judul: Perkasih

Ning ampus jenung mu

Ning muhammad jenungku
Judul: Pemikat

Saya hapus namamu

Di hatiku ada Muhammad

Mantra atau asihan di atas merupakan bentuk puisi lama yang diperoleh dari narasumber atas nama Ibu Sunan berasal dari Tiyuh Negara Ratu. Maksud mantra atau asihan di atas ialah agar setiap manusia yang dipandang atau ditatap oleh pengguna mantra dapat memikat dan menimbulkan ketertarikan dan kekaguman terhadap penggunan mantra. Mantra di atas digunakan oleh pengguna mantra hanya cukup dengan menatap lawan bicara saja sambal membaca mantra tersebut. Mantra atau asihan di atas juga dibaca rutin oleh setiap pengguna mantra dengan keyakinan penuh dan meminta pertolongan Allah setiap pagi, siang, sore atau bahkan pada saat ingin bertemu seseorang

\section{f. Judul: Superkol}

Hung sipurekal buta rasani Rekal akikko kumbok luluh Dacok kutinjuk kerbau Jalang dapok kutambang ko Seman telah ko hati anakku

Si da a na tunduk kasih lemah kasih Si dia tunduk dan cinta terhadap saya

\author{
Judul: Tunduk / Patuh \\ Biar orang tunduk buta rasa \\ Sedangkan harimau dapat luluh \\ Dapat saya tangkap kerbau liar \\ Yang liar dapat saya ikat \\ Telah ku ambil hati anakku
}

Mantra atau asihan di atas merupakan bentuk puisi lama yang diperoleh dari narasumber atas nama Ibu Pimpinan berasal dari Tiyuh Negeri Ujung Karang. Maksud mantra atau asihan di atas ialah agar orang yang kita inginkan dan kita cintai dapat tunduk dan patuh sesuai keinginan si pengguna mantra. Tujuannya adalah agar penglihatan setiap orang yang melihat pengguna mantra tersebut terlihat selalu menarik, selalu baik, cantik atau tampan dan sempurna, bahkan tidak ada satupun kekurangan di dalam diri pengguna mantra atau asihan tersebut. Mantra atau asihan di atas dibaca rutin oleh setiap pengguna dengan keyakinan penuh dan meminta pertolongan Allah setiap pagi, siang, sore atau bahkan pada saat ingin bertemu seseorang.

\section{Mantra atau asihan memperkuat mental dan rasa percaya diri}

a. Judul: Ilmu Haga Ngeberong Kawai Judul: Ilmu Berpakaian

Saunku salin cuma salin putri mekah

Ku pakai baju, seperti baju putri

Mekah

Rupaku rupa tuan baginda Rasulullah Wajahku berseri seperti baginda

Rasullah

Mantra atau asihan di atas merupakan bentuk puisi lama yang diperoleh dari narasumber atas nama Ibu Tuan Merumpun berasal dari Tiyuh Way Kanan. Maksud mantra atau asihan di atas ialah agar si pengguna mantra memiliki rasa 
percaya diri dan terlihat berwibawa, cantik/tampan oleh setiap yang melihat meskipun menggunakn pakaian yang biasa. Mantra atau asihan di atas dibaca rutin oleh setiap pengguna dengan keyakinan penuh dan meminta pertolongan Allah setiap pagi, siang, sore atau bahkan pada saat ingin bertemu seseorang.

\section{b. Judul: Ilmu Penyirop}

Ia kusambat menjadi mayat

Ia kusawat jadi batu

Rop sirop si pahat si buta jalan

Anak junjungan si pahit lidah

Lidahni patah mata ni buta mutera diri Allah

Junjunganku masuk di diri allah

Rop sirop tuan duduk para lawan dengan aku melawan
Judul: Ilmu Pembungkam Dia ku sapa menjadi mayat Dia ku tatap menjadi batu Membungkam sipahit dan si buta jalan

Anak junjungan si pahit lidah Lidahnya patah matanya buta Semua kehendak Allah

Jujungan ku segala takdir dari Allah

Membungkam dia tidak dengan ku

Mantra atau asihan di atas merupakan bentuk puisi lama yang diperoleh dari narasumber atas nama Ibu Tuan Merumpun berasal dari Tiyuh Way Kanan. Maksud mantra atau asihan di atas ialah agar ketika si pengguna mantra berbicara atau berpendapat di hadapan orang banyak (misal, dalam forum) didengarkan dan diperhatikan oleh semua orang yang berada di tempat itu, meskipun sekalipun orang-orang tidak mengenal si pengguna mantra. Mantra atau asihan di atas dibaca rutin oleh setiap pengguna dengan keyakinan penuh dan meminta pertolongan Allah setiap pagi, siang, sore atau bahkan pada saat ingin berbicara pada seseorang atau pada suatu forum.

\section{c. Judul: Ilmu Baka Makai Telesan Judul: Ilmu Memakai Basahan \\ Cetor alus jenungmu telesan \\ Santinting mutakal, lawat \\ Gunanya memakai basahan \\ Untuk menutupi, sebagian aurat}

Mantra atau asihan di atas merupakan bentuk puisi lama yang diperoleh dari narasumber atas nama Ibu Inap Triyana berasal dari Tiyuh Sinar Galih Unggak. Maksud mantra atau asihan di atas ialah agar si pengguna mantra dapat ditutupi segala aib dan kelemahan sehingga yang dilihat oleh setiap manusia hanya perilaku yang baik, berwiabawa dan tidak ada suatu kekurangan. Mantra atau asihan di atas dibaca rutin oleh setiap pengguna dengan keyakinan penuh dan meminta pertolongan Allah setiap pagi, siang, sore atau bahkan pada saat ingin bertemu seseorang.
d. Judul: Ilmu Pelapah Jelma Ramik Judul: Ilmu Berkumpul Di
Nginding sepaku inding
Paku anak mulega dewa
Seratus iring seribu iring
Aku juga dipandang mata

\section{Keramaian}
Bersandar paku dinding
Paku anak titisan dewa
Seratus iring seribu iring
Aku juga dipandang mata 
Mantra atau asihan di atas merupakan bentuk puisi lama yang diperoleh dari narasumber atas nama Pak Ajo/Darwis berasal dari Tiyuh Bumi Tinggi. Maksud mantra atau asihan di atas ialah agar si pengguna mantra ketika berbaur di tempat yang ramai, tetap menjadi pusat perhatian yang baik meskipun banyak yang mencoba membuka aibnya. Mantra atau asihan di atas dibaca rutin oleh setiap pengguna dengan keyakinan penuh dan meminta pertolongan Allah setiap pagi, siang, sore atau bahkan pada saat ingin bertemu seseorang atau pada suatu forum.

e. Judul: Ilmu Penepos Mejong

Niku mejong di alas

Nyak mejong di kursi

Rupa mu rupa mayat

Nyak rupa bidadari

\author{
Judul: Ilmu Tepuk Duduk \\ Kamu duduk di alas \\ Saya duduk di kursi \\ Rupa mu rupa mayat \\ Rupa ku rupa bidadari
}

Mantra atau asihan di atas merupakan bentuk puisi lama yang diperoleh dari narasumber atas nama Ibu Sunan berasal dari Tiyuh Negara Ratu. Maksud mantra atau asihan di atas ialah agar memperkuat mental dan rasa pecaya diri si pengguna mantra. Hal ini terlihat dari makna mantra di atas ialah agar hanya wajah si pengguna mantra terlihat seperti bidadari, namun untuk selain pengguna mantra semua terlihat seperti mayat. Mantra atau asihan di atas dibaca rutin oleh setiap pengguna dengan keyakinan penuh dan meminta pertolongan Allah setiap pagi, siang, sore atau bahkan pada saat ingin bertemu seseorang atau pada suatu forum.

\section{f. Judul: Ilmu cakak sesat}

Sesat katu jumpan sat

Sesat katu juluwang

Rop sirop cak manjung

Harimau mungan datang

\author{
Judul: Ilmu naik rumah adat \\ Rumah adat memiliki tujuh anak \\ tangga \\ Rumah adat ruang \\ Diam diam naik di junjung \\ Harimau mengamuk datang
}

Mantra atau asihan di atas merupakan bentuk puisi lama yang diperoleh dari narasumber atas nama Pak Ajo/Darwia berasal dari Tiyuh Bumi Tinggi. Maksud mantra atau asihan di atas ialah agar ketika naik rumah adat/sesat akan dipandang setiap yang melihat seolah-olah memiliki wibawa yang paling tinggi dibandingkan dengan orang yang ada pada saat itu. Cakak sesat ini adalah sebuah proses pengambilan gelar adat yang dilakukan oleh masyarakat adat Lampung Pepadun. Mantra atau asihan di atas dibaca pada saat menaiki rumah adat yang telah disediakan oleh masyarakat adat. 


\section{Mantra atau Asihan Mengalahkan Kekuatan Alam Sekitar}

a. Judul: Hiji Ilmu Buil

Sinan jah sinan jinnah

Sisakkan sialiyan buku mesolpai

Niku akuk kembamg di tiyuh Sebarhara
Judul: Ilmu Membuang Sial

Belas kasih dari orang

Sisakan kesialan yang telah ditetapkan

Kau ambil bunga di desa Sembahara

Mantra atau asihan di atas merupakan bentuk puisi lama yang diperoleh dari narasumber bernama Ibu Pimpinan berasal dari Tiyuh Negeri Ujung Karang. Maksud mantra atau asihan di atas ialah agar si pengguna mantra terhindar dari kesialan yang telah ditetapkan takdir menimpanya ketika melakukan suatu pekerjaan. Mantra atau asihan di atas dibaca rutin oleh setiap pengguna dengan keyakinan penuh dan meminta pertolongan Allah setiap pagi, siang, sore serta pada saat memulai melakukan aktivitas.

\section{Mantra atau Asihan Mengobati Orang Sakit}

a. Judul: Ilmu Racun

Pangeghan Raja bias

Biasa bisa rasa bias

Telu ngepuluh telu rin ilmu racun tawar

Dalah setitih jak lom jantung

Mula jadi ramuan tawar

\author{
Judul: Ilmu Penawar Racun \\ Pangeran Raja Beras \\ Biasa racun terasa beras \\ Tiga puluh tiga dirimu racun tawar \\ Darah setetes dari dalam jantung \\ Maka jadi penawar racun
}

Mantra atau asihan di atas merupakan bentuk puisi lama yang diperoleh dari narasumber bernama Ibu Pimpinan berasal dari Tiyuh Negeri Ujung Karang. Maksud mantra atau asihan di atas ialah agar pengguna mantra kebal terhadap racun yang diberikan oleh orang yang ingin mencelakainya. Tujuan dari mantra tersebut untuk menangkal kejahatan atau racun yang diberikan dalan bentuk makanan atau minuman yang mematikan. Mantra atau asihan di atas dibaca rutin oleh setiap pengguna dengan keyakinan penuh dan meminta pertolongan Allah setiap pagi, siang, sore atau bahkan pada saat ingin bertemu seseorang.

\section{Kesimpulan}

Hasil analisis yang telah dilakukan pada asihan (mantra) sebanyak empat belas mantra yang didapati dari sumber data sebanyak empat tetua adat budaya Lampung, terdapat enam asihan (mantra) yang berfungsi untuk menundukkan hati seseorang dengan judul 'Busalin, Ngerang Telesan, Ilmu Bumiyah Muli Meranai, Pungijak Jak Cahya, Perkasih, dan Superkol', enam asihan (mantra) berfungsi untuk memperkuat mental dengan judul 'Ilmu Haga Ngeberong Kawai, Ilmu Penyirop, Ilmu Baka Makai Telesan, Ilmu Penepos Mejong, dan Ilmu cakak sesat', satu asihan (mantra) berfungsi untuk mengalahkan kekuatan 
di alam sekitar dengan judul 'Hïji Ilmu Buil', dan terdapat satu asihan (mantra) berfungsi untuk mengobati penyakit pada orang yang menderita sakit dengan judul 'Ilmu Racun'.

\section{Daftar rujukan}

Hadikusuma, H. (1988). Bahasa Lampung. CV. Fajar Agung Jakarta.

Hutomo, S. S. (1991). Mutiara yang Terlupakan. Himpunan.

Irawan, Wi. D. (2019). Sistem Kekerabatan Masyarakat Lampung Pepadun Berdasarkan Garis Bertalian Darah. Edukasi Lingua Sastra, 2.

James, D. (2007). Foklor Indonesia: Ilmu, Gosip, Dongeng, dan Lain-lain. Pustaka Utama Grafiti.

Moleong, L. J. (2005). Metodologi Penelitian Kualitatif. Remaja Rosdakarya.

Pradopo, R. D. (2002). Pengkajian Puisi. Gadjah Mada University Press.

Rani, S. A. (1996). Ikhtisar Sastra Indonesia. Pustaka Setia.

Sanusi, A. E. (2013). Sastra Lisan Lampung. Universitas Lampung press.

Simatupang, M. D. S. (1999). Pengantar Teori Terjemahan. Direktorat Jenderal Pendidikan Tinggi Departemen Pendidikan Nasional. 